\title{
High Speed Rail Passenger Satisfaction According to Socio-Demographic Variables in Turkey
}

\author{
Türkiye'de Sosyodemografik Değişkenlere Göre \\ Yüksek Hızlı Tren Yolcu Memnuniyeti
}

\author{
Seher ÖZKAZANÇ
}

ABSTRACT

This study evaluates the high speed rail (HSR) satisfaction from the perspective of passengers of different socio-demographic structures. The population of the study consisted of 427 individuals who are older than 18 years old and the main scope of the study was on AnkaraKonya HSR route, which constitutes $28 \%$ of the total HSR trips, at the economy class. In the present study, in line with the data obtained from the literature, 23 sub-criteria sets under 6 main headings that are expected to affect passenger satisfaction are provided to the users in a questionnaire form. To weight the determined criteria according to the degree of importance, the analytic hierarchy process (AHP) method was used and expert opinion was referred. When AHP analysis results were examined, trip and train comfort were determined to have more impact on passenger satisfaction in the main criteria, while fare, ticket services, and train service times had more impact in the sub-criteria. Considering the gender variable, it is found that female participants differ from male participants in terms of trip comfort and security and risk satisfaction. HSR overall satisfaction level was identified to decrease as the level of age and education increases. The early-aged and aged group (55 and over age) delivered a negative opinion for train comfort in particular. Station comfort satisfaction score was found to be inversely proportionated to income, while fare and ticket services total satifaction score was direclty proportionated to income. Considering the general satisfaction scores according to the trip purposes; it was determined that participants traveling with the aim of visiting their friends and participating in socio-cultural activities were found to be more satisfied with HSR, while the participants traveling for care services, on the other hand, were found to have the lowest satisfaction score.

Keywords: Analytic hierarchy process; customer satisfaction; high speed rail; passenger satisfaction; service quality.

Öz

Bu çalışmada, yüksek hızlı tren memnuniyeti farklı sosyodemografik yapıdaki yolcuların bakış açısıyla değerlendirilmektedir. Çalışmanın örneklemini Ankara-Konya yüksek hızı tren güzergahında seyahat eden, 18 yaşından büyük, ekonomi sınıfını kullanan 427 kişi oluşturmaktadır. Çalışmada literatürden elde edilen bilgiler doğrultusunda yolcuların memnuniyetine etki edeceği öngörülen altı ana başlıkta 23 alt kriter seti anket formu şeklinde kullanıcılara sunulmuş, anketlerde likert tipi ölçek kullanılmıştır. Belirlenen kriterlerin önem derecesine göre ağırlıklandırılması amacıyla analitik hiyerarşi süreci yönteminden yararlanılarak uzman görüşüne başvurulmuştur. Analitik hiyerarşi süreci analiz sonuçları incelendiğinde ana kriterlerde yolculuk ve tren konforu; alt kriterlerde ise sefer sıklığı, bilet ücreti ve sefer saatlerinin yolcu memnuniyetine daha fazla etki ettiği saptanmıştır. Cinsiyet değişkeni ele alındığında kadın katılımcıların erkek katılımcılardan tren konforu ile güvenlik ve risk memnuniyetinde farklılaştıkları görülmüştür. Yüksek hızlı tren genel memnuniyet düzeyinin, yaş ve eğitim düzeyi arttıkça azaldığı saptanmıştır. Erken yaşlıyaşlı grubu (55 yaş ve üzeri) özellikle tren konforuna ilişkin olumsuz görüş bildirmiştir. İstasyon konforu memnuniyet puanının gelirle ters orantılı, ücret ve bilet hizmetleri toplam memnuniyet puanının gelirle doğru orantılı olduğu tespit edilmiştir. Yolculuk amaçlarına göre genel memnuniyet puanlarına bakıldığında arkadaş ziyareti ve sosyokültürel etkinliklere katılım amacıyla yolculuk yapan katılımcıların yüksek hızlı trenden daha memnun olduğu; bakım hizmeti amacıyla yolculuk yapan katılımcıların ise en düşük memnuniyet puanına sahip olduğu saptanmıştır.

Anahtar sözcükler: Analitik hiyerarşi süreci; müşteri memnuniyeti; yüksek hızlı tren; yolcu memnuniyeti; hizmet kalitesi.

Department of City and Regional Planning, Necmettin Erbakan University Faculty of Engineering and Architecture, Konya, Turkey

Article arrival date: May 19, 2020 - Accepted for publication: December 11, 2020

Correspondence: Seher ÖZKAZANÇ. e-mail: seherpolat7@gmail.com

○ 2021 Yıldız Teknik Üniversitesi Mimarlık Fakültesi - ๑ 2021 Yıldız Technical University, Faculty of Architecture 


\section{Introduction}

High speed rails, considered one of the most significant technological developments in passenger transportation, were developed in the second half of the 20th century. In a historical perspective, railways were reaching 100 $\mathrm{km} / \mathrm{h}$ until 1850's, $130 \mathrm{~km} / \mathrm{h}$ in 1854 and $200 \mathrm{~km} / \mathrm{h}$ in the beginning of the 20th century. After some noteworthy speed records in Europe (see Germany, Italy, UK and France), in 1964, Japanese national railways launched an entirely new high-speed line, and this date was considered to be the milestone of HSR. The following countries followed suit, offering HSR trip in Europe, respectively: Italy and Germany in 1988, Spain in 1992, Belgium in 1997, England in 2003 and the Netherlands in 2009. This development was followed by other countries and regions, China was included in the HSR system in 2003, South Korea in 2004, and Taiwan in 2007 (UIC, 2019).

High speed railway has become one of the main transportation means for long-distance passenger transportation in the world (Liu et al., 2012). Hence, HSR differs from other transportation systems with its features such as security, strong carrying capacity, low energy consumption, speed, time advantage and being environmentally friendly (Cao \& Chen, 2011). It is predicted, therefore, by 2030-2035, that the established HSR network will be more than 80,000 kilometers across the world (UIC, 2019).

Railway transportation in Turkey, in parallel with the developments in the world, gained acceleration with the introduction of HSR in 2009. Turkish State Railways (TCDD) tries to spread the HSR services out across the country. In this context, the following lines were implemented respectively: Ankara-Eskisehir in 2009, Ankara-Konya in 2011 and Ankara-Istanbul and Konya-Istanbul lines in 2014. The lines between Ankara-Izmir, Ankara-Sivas, Bursa-
Bilecik and Konya-Karaman are other planned HSR lines to be implemented (Figure 1). Every year, there is an increase in the number of passengers using HSR, for example, in 2018 , the total number of passengers increased by $13 \%$ compared to the previous year (TCDD, 2018).

As in the world, HSR attracts a significant number of passengers in Turkey, especially in the transportation market for long-distance trip. To maintain this trend, the quality of passenger services is one of the main concerns of railway operators (Nathanail, 2008); in addition to providing passenger satisfaction and loyalty, service quality ensures keeping the operator in a competitive position in the field of passenger transportation (Kotler, 1997). In the competitive market conditions, organizations increasingly feel the importance of establishing good relationships with their customers, and therefore, make efforts to meet customer expectations (Wang, et al., 2007). Measuring perceptions of the services provided and determining the expectations and demands regarding these services help improve the quality of passenger transportation companies (Alpu, 2015). Increasing the share of public transportation in transportation systems takes its place in urban policies for a sustainable environment. Service quality and therefore customer satisfaction are two important factors for orientation to public transportation. Customer satisfaction and perceived service quality are related to each other and passengers who perceive quality public transport continue to use this service (Chen, 2008; Jen \& Hu, 2003; Kilibarda et al., 2016; Lai \& Chen, 2011).

While the main requirement of passengers in the past was to get from one place to another, today, the trip frequency increasing with the improvement of the economy and living standards has brought with it an increasing demand for comfort. Thus, the quality and satisfaction have become more and more important in creating corporate image and competitiveness (Chin et

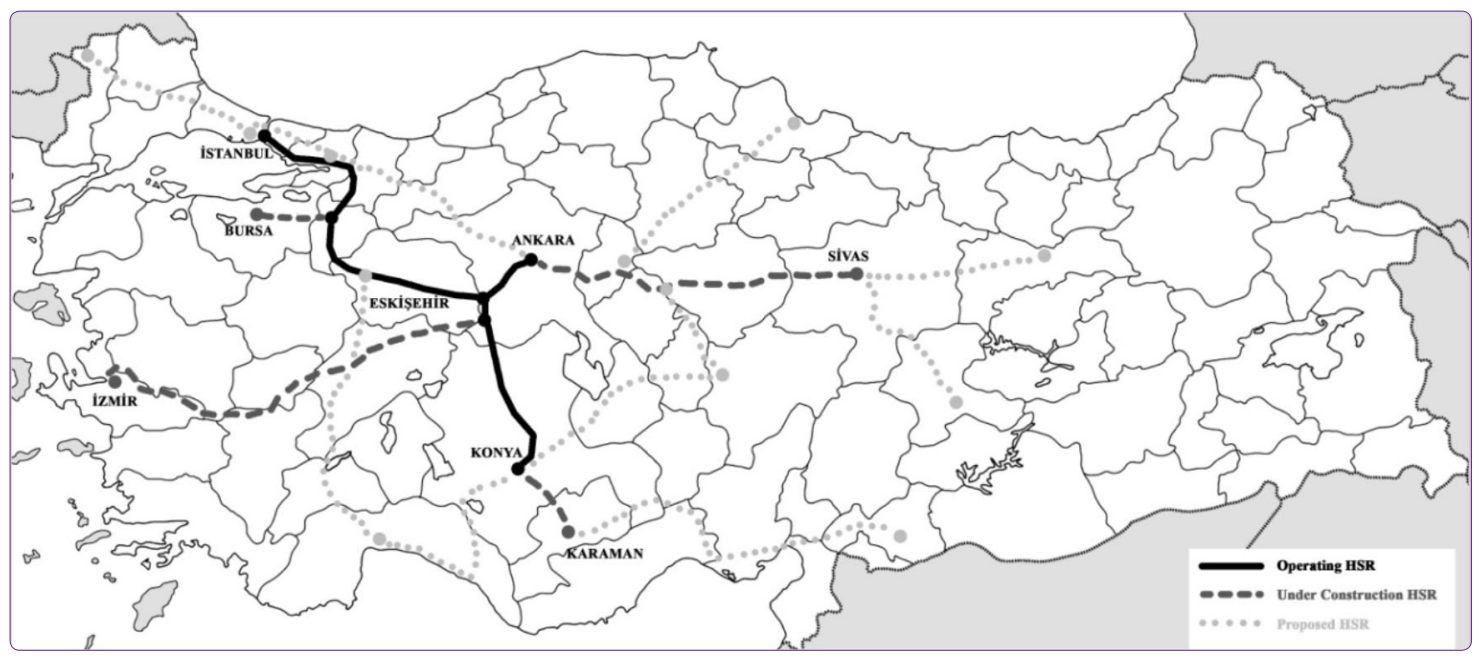

Figure 1. Turkey high-speed rail network (TCDD, 2018; Ray Haber, 2020). 
al., 2019). This increased interest in customer satisfaction, on the other hand, made it compulsory for transport companies to define and measure the parameters that cause the satisfaction or dissatisfaction of their passengers (Agarwal, 2008).

While current studies recognize the importance of improving the quality of service and its component passenger satisfaction to some extent, there are still some gaps in reaching an HSR service with high passenger satisfaction (Chin et al., 2019). The first of these gaps is the absence of sufficient research on how to improve passenger satisfaction (from passenger perspective). The second point is the determination of satisfaction levels regardless of the socio-demographic structure of the user group; whereas, many variables such as age, gender, education, profession, etc. affect satisfaction differently. The present study, therefore, focuses on examining the satisfaction levels of TCDD high-speed rail passengers by considering their socio-demographic characteristics, improving the HSRs in the light of this information and increasing the number of HSR passengers and their satisfaction with these trips. In this regard, weight calculation was made through analytic hierarchy process (AHP) method for both main criteria and sub criteria and later, questionnaire technique was implied to collect data in this study. The questionnaires comprise of 6 basic and 23 sub-criteria, besides, these criteria are weighted using the AHP method, where expert opinion is obtained. Thus, the needs and expectations of the passengers are classified according to priorities, and the overall accuracy and reliability of the obtained results were increased.

\section{Literature Review}

Customer satisfaction depends on the quality of the product (or service) provided (Anderson \& Sullivan, 1993), therefore, service quality and satisfaction are highly related (Liu et al., 2005; Olsen, 2002). However, due to the reasons such as multi-dimensional structure of service quality, and the presence of few scales specific to service quality particularly in the transport industry (measurement problems) (Wu \& Lin, 2011), determining customer (passenger) satisfaction instead of service quality gives more tangible results. As a matter of fact, various studies measuring customer satisfaction, service quality and degree of commitment to HSR revealed that satisfaction directly affects trip behaviors, while service quality and corporate image play an indirect role (Cao \& Chen, 2011; Chou \& Kim, 2009; Kuo \& Tang, 2011; Nathanail, 2008). This study, therefore, examines customer satisfaction rather than service quality.

$\mathrm{Hu}$ et al. (2009) describe customer satisfaction as a cognitive or affective response that corresponds to a single or long-term service provider; while Eroğlu (2005), on the other hand, defines this as the difference arising from the expectations of the customer and the consumption or usage. Customer satisfaction is discussed with different criteria for each service area; a literature review on public transport and HSR was carried out within the study.

Joewono and Kubota (2007) have defined the criteria for availability, accessibility, reliability, information, customer service, comfort, safety, price and environmental impact of Indonesian paratransit systems; while Silcock (1981) has characterized criteria for accessibility, reliability, comfort, convenience and security measures in public transport. Cheng (2011) has evaluated website service quality in public transportation; while Parasuraman et al. (1988) addressed five criteria: reliability, responsiveness, tangibility, assurance, and empathic. Pullen (1993) considered the accessibility, reliability, comfort, convenience and safety criteria in local public transport; de Oña et al. (2018) on the other hand, discussed customer service, tangible service equipment, availability of the service, individual space, accessibility, information, security, environmental pollution (noise, vibration) criteria. As is seen, criteria such as frequency, reliability, comfort, security, information, personnel behavior, cleaning, ticketing and price are among the most used criteria in public transportation studies (Lao \& Liu, 2009). Among these criteria determined in public transportation, on the other hand, Dell'Olio et al. (2011) state that hygiene, comfort and time of waiting; while Redman et al. (2013) service security and frequency; and Mouwen and Rietveld (2013), on the other hand, state that the factors such as service frequency, trip speed, and precision have more impact on passenger satisfaction.

In terms of railway transportation, Rothbauer and Sieg (2011) lists the quality and satisfaction criteria as safety, hygiene, passenger comfort, service frequency, and speed; while Harvey et al. (2014) states them as reliability, safety, convenience, comfort, flexibility, cost, trip time, and amenities. In his study on Turkish State Railways, Zeybek (2018) examined transit time, availability of wagons, accessibility, loss and damage, secure transport, reliability, flexibility, distance, technical equipment, price-quality ratio; while Aydin et al. (2015) investigated the criteria of train comfort, ticketing, information systems, safety, accessibility, station comfort, welcoming, fare, and time. Chou et al.(2011); Xiaoqiang et al. (2017) suggested a passenger satisfaction index and evaluated the overall satisfaction, proper price tolerance and the effects of the ticket service system. The common criteria for railway passenger satisfaction can be summarized as reliability, safety and security, convenience, and comfort (Allen \& DiCesare, 1976; Miller, 1995; Pullen, 1993). 
Studies addressing railway passenger satisfaction more specifically can be listed as suitability of train stations for the elderly (Zhao et al., 2018), thermal comfort of stations (Y. Liu \& Yang, 2018) and customer satisfaction in the cabin (Chin et al., 2019). The sub-criteria used in HSR passenger satisfaction are quite diverse, these are stable internet connections, sufficient sockets and noiseless trip environment (Tang et al., 2018); well-transmitted information, proper luggage storage, sensory comfort, civilized riding environment, well-prepared facilities (Chin et al., 2019); train performance (delays per passenger train), overcrowding, safety or accident risk (Pollitt \& Smith, 2002); comfortable seat, cleanliness of sitting area (Drea \& Hanna, 2000; Hanna \& Drea, 1998).

Vanniarajan and Stephen (2008) evaluated passenger satisfaction using the data collected from the passengers of the Southern Railways and identified the factors of reliability, assurance and empathy for passengers. In his study on Indian Railways, Agarwal (2008) analyzed 47 different qualities such as ticket, platform, trip and employee behavior, and stated that employee behavior among these various factors considered has greatly affected customer satisfaction. Alpu (2015) has determined 4 factors: physical conditions, food services, information and personnel behavior. But she found that the most important contribution to customer satisfaction was provided by the attitude and behavior of the staff. In her study on Helenic railways, Nathanail (2008) examined 6 criteria such as cleanliness, itinerary accuracy, system safety, passenger comfort, servicing, and passenger information and determined that itinerary accuracy and system safety criteria were more effective in satisfaction. Nandan (2010) took 16 variables to measure service quality in Indian railways and stated that safety and security, basic facilities, information system, behavioral factors and refreshments factors were effective in order of priorities. Zhen et al. (2018) reported that the highest correlation regarding passenger satisfaction was staff attitude, ease of booking and accessibility.

As can be seen, passenger satisfaction differs in every society and even in every sample group (customer satisfaction criterias are presented in Table A.1). For this reason, companies need to understand the different needs of customers in using distribution channels in order to provide suitable and quality service to the passengers (Cheng \& Huang, 2014).

In this context, the objectives of the present study can be listed as follows:

- To determine the factors and importance levels affecting the satisfaction of HSR passengers,

- To analyze the general satisfaction perceptions of the passengers on HSR,
- To compare the satisfaction levels of the passengers with different trip purposes and different sociodemographic structures.

\section{Empirical Study and Results}

\section{Ankara-Konya HSR}

HSR trips between Ankara, the capital city of Turkey, and Konya, which is the 1st in terms of the surface area of the country and the 7th largest city in terms of population, constitute the scope of this study. Today, the Ankara-Konya line, which constitutes $28 \%$ of the total HSR trips, has a transportation share of $66 \%$ after its opening. As of 2018 , a total of 2,242,870 passengers were transported on the Ankara-Konya route and 6,606 train runs were performed. During these runs, an average of 4,800 people on weekdays and 5,500 people on weekends are transported. On the 1 hour 45 minutes-line, there are 20 daily trips in summer, and 14 trips in the winter season. On the Ankara-Konya route, trains stop at Eryaman and Polatlı stations. There are no stations on the Konya-Ankara route yet.

On the Ankara-Konya line, Siemens Velaro branded trains are used, consisting of 8 carriages, 1 of which is a cafeteria. These trains have portable catering, air conditioning, and music systems, special seating areas for the disabled and vacuum toilets. The train capacity is 483 people, including 424 economy class, 57 business class and 2 disabled (wheelchair-bound) passengers.

\section{Methodology and Data Collection}

To measure HSR passenger satisfaction, a questionnaire was applied during the trips at different times of the day to 427 people (confidence interval is $95 \%$ ) aged over 18 years old between the dates of 14-20 May 2018 (education continues on these dates) with the approval of TCDD. 234 (54.8\%) people on the Ankara-Konya line and 193 $(45.2 \%)$ people on the Konya-Ankara line completed the questionnaire, while 128 questionnaires were excluded since they were not completed and 194 questionnaires were excluded since they were left blank.

The questionnaires were prepared including three main sections: the socio-demographic information of the participants, their trip information and their evaluation of HSR satisfaction. The majority of the participants were young, highly-educated and non-employed individuals (Table 1). Those who were not working were comprising of: $70.4 \%$ students, $6.7 \%$ sick/disabled, $5.6 \%$ housewives, and $10.6 \%$ retired.

When the trip information of the participants is examined, it is seen that the trips are made for the following purposes: visiting relatives (29.3\%), business and business follow-up (28.1\%), education (17.2\%), friend visit (11.5\%), participation in social and cultural events (8.1\%), health services $(3.7 \%)$, child, elderly and patient 
care (2.0\%). Besides, $31.8 \%$ of the respondents use HSR at least once a week (Table 2).

In light of the information obtained from the literature, 23 sub-criteria under 6 main headings (Table 3 ) were

Table 1. Demographic profile of questionnaire respondents of HSR passengers

\begin{tabular}{|c|c|c|c|}
\hline Variable & Variable level & Frequency & $\begin{array}{l}\text { Valid } \\
\text { Percent }\end{array}$ \\
\hline \multirow[t]{6}{*}{ Age } & 18-24 years & 149 & 35.6 \\
\hline & 25-34 years & 129 & 30.8 \\
\hline & $35-44$ years & 77 & 18.4 \\
\hline & $45-54$ years & 35 & 8.4 \\
\hline & $55-64$ years & 25 & 5.9 \\
\hline & 65 and over & 4 & 0.9 \\
\hline \multirow[t]{2}{*}{ Gender } & Female & 177 & 41.5 \\
\hline & Male & 250 & 58.5 \\
\hline \multirow[t]{3}{*}{ Marital status } & Married & 185 & 43.6 \\
\hline & Single & 231 & 55.5 \\
\hline & Divorced / widowed & 8 & 1.9 \\
\hline \multirow[t]{5}{*}{ Education } & Primary school & 14 & 3.3 \\
\hline & Secondary school & 20 & 4.7 \\
\hline & High school & 82 & 19.3 \\
\hline & University & 221 & 52.2 \\
\hline & Graduate & 87 & 20.5 \\
\hline \multirow[t]{4}{*}{ Occupation } & Unemployed & 163 & 39.4 \\
\hline & Private sector workers & 145 & 35.0 \\
\hline & Public sector workers & 77 & 18.6 \\
\hline & Self-employment & 29 & 7.0 \\
\hline \multicolumn{4}{|l|}{ Income } \\
\hline \multirow[t]{6}{*}{$(1 \mathrm{YTL}=0,17 \$)$} & $0-500$ YTL & 67 & 17.2 \\
\hline & 501-1500 YTL & 34 & 12.6 \\
\hline & $1501-2000 \mathrm{YTL}$ & 42 & 8.7 \\
\hline & 2001-3000 YTL & 49 & 15.9 \\
\hline & $3001-4000 \mathrm{YTL}$ & 62 & 10.8 \\
\hline & 4001 and over & 135 & 34.8 \\
\hline
\end{tabular}

determined to affect the satisfaction of the passengers. In this section of the survey, a 5-point Likert-type assessment scale was used (1:"strongly disagree", 5:"strongly agree"). Based on the assumption that these criteria will not have the same importance for passengers and will have different effects on satisfaction, the analytic hierarchy process method was used and criteria weights were determined based on expert opinion.

\section{Analytic Hierarchy Process}

Analytic hierarchy process (AHP), which was developed by Thomas L. Saaty in the 1970s, is a method frequently used in decision-making mechanisms (Saaty, 2008). AHP is simple in logical explanation, but based on mathematical hypotheses and assumptions in its own process and provides multi-criteria decision-making opportunity among the alternatives (Lee et al., 2009). Unlike other multi-criteria decision-making methods, AHP compares the criteria in pairs and measures whether the comparisons are consistent.

The first five steps to achieve criteria weights through AHP are: identification of the problem, determining and defining the main and sub-criteria of decision, determining the alternatives, creating the hierarchical structure, and determining the importance scale (Table 4) (Uludağ \& Doğan, 2016).

In the sixth step, pairwise comparison matrix is created. The created comparison matrix is normalized. For this operation, column totals are taken and each value is divided by its own column total. The next step is to create the weight matrix and calculate the Consistency Ratio (CR). CR is obtained by the ratio of Consistency Index (CI) to Random Index (RI) (Table 5). In AHP applications, the fact that CR is less than 0,10 indicates that the application is consistent (Saaty, 1980).

Empirical Results

In the study, firstly, weight calculation was made through AHP method for both main criteria and sub criteria (Table 6-13).

Table 2. HSR trip purposes and trip frequency

\begin{tabular}{|c|c|c|c|c|c|c|c|c|}
\hline & \multicolumn{8}{|c|}{ Trip Purposes (\%) } \\
\hline & $\begin{array}{c}\text { Frequency } \\
\text { (\%) }\end{array}$ & $\begin{array}{l}\text { Health } \\
\text { Services }\end{array}$ & $\begin{array}{l}\text { Friend } \\
\text { visit }\end{array}$ & $\begin{array}{l}\text { Social and } \\
\text { cultural } \\
\text { activity }\end{array}$ & Education & $\begin{array}{l}\text { Child and } \\
\text { patient } \\
\text { care }\end{array}$ & $\begin{array}{l}\text { Visiting } \\
\text { of } \\
\text { relatives }\end{array}$ & $\begin{array}{c}\text { Business and } \\
\text { business } \\
\text { follow-up }\end{array}$ \\
\hline \multicolumn{9}{|l|}{ Trip Frequency } \\
\hline Several times a year & 19.4 & 20.0 & 29.0 & 38.6 & 10.8 & 0.0 & 17.7 & 18.4 \\
\hline Once a month & 26.3 & 45.0 & 27.4 & 20.5 & 20.4 & 45.5 & 34.2 & 19.1 \\
\hline 2-3 times a month & 23.1 & 15.0 & 25.8 & 27.3 & 30.1 & 18.2 & 25.9 & 15.1 \\
\hline 1-2 times a week & 5.4 & 0.0 & 6.5 & 4.5 & 8.6 & 0.0 & 5.7 & 3.9 \\
\hline 3-4 times a week & 20.4 & 20.0 & 11.3 & 9.1 & 30.1 & 36.4 & 16.5 & 24.3 \\
\hline 5 and above a week & 5.4 & 0.0 & 0.0 & 0.0 & 0.0 & 0.0 & 0.0 & 19.1 \\
\hline
\end{tabular}


Table 3. Satisfaction criteria

\begin{tabular}{|c|c|c|}
\hline Main Criteria & Code & Sub Criteria \\
\hline \multirow[t]{4}{*}{ Security and risk (S) } & S1 & Security measures for emergencies and disasters \\
\hline & S2 & Security measures for theft, harassment, etc. \\
\hline & S3 & Security measures in the station and its vicinity \\
\hline & S4 & Insurance against accident risk \\
\hline \multirow[t]{3}{*}{ Fare and ticket services (F) } & F1 & Fare \\
\hline & $\mathrm{F} 2$ & $\begin{array}{l}\text { Special discounts (TCDD charges a low fee for groups such as disabled, teacher, retired, student, } 65 \\
\text { years old, etc.) }\end{array}$ \\
\hline & F3 & Accessibility for ticket services and information \\
\hline \multirow[t]{3}{*}{ Station comfort (SC) } & SC1 & Comfort of passenger lounge \\
\hline & SC2 & Platform compatibility \\
\hline & $\mathrm{SC} 3$ & Compatibility of stations to climatic conditions \\
\hline \multirow[t]{4}{*}{ Trip comfort (T) } & $\mathrm{T} 1$ & Passenger density \\
\hline & $\mathrm{T} 2$ & Trip frequency \\
\hline & T3 & Trip hours \\
\hline & T4 & $\begin{array}{l}\text { Sex discrimination in seats (TCDD does not allow female and male passengers to sit side by side out } \\
\text { of their own will for security reasons) }\end{array}$ \\
\hline \multirow[t]{4}{*}{ Personnel behavior (PB) } & PB1 & Attitude of service personnel \\
\hline & PB2 & Attitude of ticket controllers \\
\hline & PB3 & Attitude of booking office personnel \\
\hline & PB4 & Returning to complaints \\
\hline \multirow[t]{5}{*}{ Train comfort (TC) } & $\mathrm{TC} 1$ & Cleaning (seat, floor, window, wc, etc.) \\
\hline & $\mathrm{TC} 2$ & Width of seating areas \\
\hline & $\mathrm{TC} 3$ & Ventilation and heating system \\
\hline & TC4 & Sound-noise level \\
\hline & TC5 & Suitability for disadvantaged people (disabled, elderly, child, etc.) \\
\hline
\end{tabular}

Table 4. Cross-criteria significance scale (Saaty, 1990)

\begin{tabular}{ll}
\hline Significance Level (aij) & Description \\
\hline 1 & $\begin{array}{l}\text { i and j are equally important } \\
\text { i criterion slightly more important } \\
\text { than j criterion }\end{array}$ \\
5 & $\begin{array}{l}\text { i criterion obviously more } \\
\text { important than j criterion } \\
\text { i criterion highly more important } \\
7\end{array}$ \\
9 & $\begin{array}{l}\text { j criterion } \\
\text { i criterion extremely more important } \\
\text { j criterion } \\
\text { Intermediate values }\end{array}$ \\
\hline
\end{tabular}

Table 5. Index values of average random consistency (Saaty, 2008)

\begin{tabular}{lccccccccc}
\hline Degree & $\mathbf{1}$ & $\mathbf{2}$ & $\mathbf{3}$ & $\mathbf{4}$ & $\mathbf{5}$ & $\mathbf{6}$ & $\mathbf{7}$ & $\mathbf{8}$ & $\mathbf{9}$ \\
\hline $\mathrm{RI}$ & 0.00 & 0.00 & 0.58 & 0.90 & 1.12 & 1.24 & 1.32 & 1.41 & 1.45
\end{tabular}

When the main criteria matrix is examined, it is seen that the consistency is high $(C R=0.0297)$ and weights are ranked as $\mathrm{T}>\mathrm{TC}>\mathrm{F}>\mathrm{S}>\mathrm{SC}>\mathrm{PB}$ (Table 6).

The consistency of the security and risk sub-criteria matrix is high and the weight order is S1> S3> S2> S4 (Table 7). Being located of Turkey in a geography with high disaster risk and the terrorist attack on Ankara train station in 2015 increased the weight of the S1 and S3 criteria.

The consistency of the fare and ticket services sub-criteria matrix is very high (Table 8). Ticket prices appear to be highly effective in satisfaction (weight ranking F1> F2> F3).

The consistency of the station comfort sub-criteria matrix is high. When the results were evaluated, the compliance of the stations to the climatic conditions was found to be more effective in satisfaction as a result of the expert opinion (Table 9; weight ranking SC3 $>\mathrm{SC} 2>\mathrm{SC} 1$ ). To avoid confusion since there are two stations on the Ankara route and the main station is located within the shopping center; only Konya station was included in the evaluation. Ankara and Konya are the cities where severe climate (cold-dry) conditions are often experienced. 
The consistency of the trip comfort sub-criteria matrix has the highest weight. In reservations or bookings, seats is high (Table 10). Among these criteria, the trip frequency

Table 6. Pairwise comparison matrix and weights of the main criteria

\begin{tabular}{|c|c|c|c|c|c|c|c|}
\hline & $\mathbf{S}$ & $\mathbf{F}$ & sC & $\mathbf{T}$ & PB & TC & Weights \\
\hline Security and risk (S) & 1 & $1 / 3$ & 2 & $1 / 5$ & 3 & $1 / 2$ & 0.089 \\
\hline Fare and ticket services (F) & 3 & 1 & 5 & $1 / 3$ & 7 & 2 & 0.233 \\
\hline Station comfort (SC) & $1 / 2$ & $1 / 5$ & 1 & $1 / 7$ & 2 & $1 / 3$ & 0.054 \\
\hline Trip comfort (T) & 5 & 3 & 7 & 1 & 9 & 4 & 0.452 \\
\hline Personnel behavior (PB) & $1 / 3$ & $1 / 7$ & $1 / 2$ & $1 / 9$ & 1 & $1 / 4$ & 0.034 \\
\hline Train comfort (TC) & 2 & $1 / 2$ & 3 & $1 / 4$ & 4 & 1 & 0.138 \\
\hline
\end{tabular}

$\lambda \max =6.1844 \mathrm{CR}=0.0297<0.10$

Table 7. Pairwise comparison matrix and weights of security and risk sub-criteria

\begin{tabular}{|c|c|c|c|c|c|}
\hline & S1 & S2 & S3 & S4 & Weights \\
\hline Security measures for emergencies and disasters (S1) & 1 & 4 & 2 & 7 & 0.508 \\
\hline Security measures for theft, harassment, etc. (S2) & $1 / 4$ & 1 & $1 / 2$ & 4 & 0.160 \\
\hline Security measures in the station and its vicinity (S3) & $1 / 2$ & 2 & 1 & 5 & 0.276 \\
\hline Insurance against accident risk (S4) & $1 / 7$ & $1 / 4$ & $1 / 5$ & 1 & 0.056 \\
\hline
\end{tabular}

$\lambda \max =4.0911 \mathrm{CR}=0.0337<0.10$

Table 8. Pairwise comparison matrix and weights of fare and ticket services sub-criteria

\begin{tabular}{lcccc}
\hline & F1 & F2 & F3 & Weights \\
\hline Fare (F1) & 1 & 4 & 6 & 0.701 \\
Special discounts (F2) & $1 / 4$ & 1 & 2 & 0.193 \\
Accessibility for ticket services and information (F3) & $1 / 6$ & $1 / 2$ & 1 & 0.106 \\
\hline
\end{tabular}

$\lambda \max =3.0148 C R=0.0128<0.10$

Table 9. Pairwise comparison matrix and weights of station comfort sub-criteria

\begin{tabular}{lcccc}
\hline & SC1 & SC2 & SC3 & Weights \\
\hline Comfort of passenger lounge (SC1) & 1 & $1 / 3$ & $1 / 6$ & 0.096 \\
Platform compatibility (SC2) & 3 & 1 & $1 / 3$ & 0.251 \\
Compatibility of stations to climatic conditions (SC3) & 6 & 3 & 1 & 0.653 \\
\hline
\end{tabular}

$\lambda \max =3.0272 \mathrm{CR}=0.0234<0.10$

Table 10. Pairwise comparison matrix and weights of trip comfort sub criteria

\begin{tabular}{lccccc}
\hline & T1 & T2 & T3 & T4 & Weights \\
\hline Passenger density (T1) & 1 & $1 / 9$ & $1 / 6$ & $1 / 4$ & 0.047 \\
Trip frequency (T2) & 9 & 1 & 2 & 4 & 0.510 \\
Trip hours (T3) & 6 & $1 / 2$ & 1 & 3 & 0.305 \\
Sex discrimination in seats (T4) & 4 & $1 / 4$ & $1 / 3$ & 1 & 0.138 \\
\hline
\end{tabular}

$\lambda \max =4.0906 \mathrm{CR}=0.0336<0.10$ 
Table 11. Pairwise comparison matrix and weights of personnel behavior sub-criteria

\begin{tabular}{|c|c|c|c|c|c|}
\hline & PB1 & PB2 & PB3 & PB4 & Weights \\
\hline Attitude of service personnel (PB1) & 1 & 5 & 2 & 3 & 0.467 \\
\hline Attitude of ticket controllers (PB2) & $1 / 5$ & 1 & $1 / 4$ & $1 / 2$ & 0.079 \\
\hline Attitude of booking office personnel (PB3) & $1 / 2$ & 4 & 1 & 3 & 0.315 \\
\hline Returning to complaints (PB4) & $1 / 3$ & 2 & $1 / 3$ & 1 & 0.139 \\
\hline
\end{tabular}

$\lambda \max =4.0748 C R=0.0276<0.10$

Table 12. Pairwise comparison matrix and weights of train comfort sub-criteria

\begin{tabular}{lcccccc}
\hline & TC1 & TC2 & TC3 & TC4 & TC5 & Weights \\
\hline Cleanliness (TC1) & 1 & $1 / 3$ & 3 & 2 & 3 & 0.221 \\
Width of seating areas (TC2) & 3 & 1 & 6 & 3 & 6 & 0.486 \\
Ventilation and heating system (TC3) & $1 / 3$ & $1 / 6$ & 1 & $1 / 2$ & 1 & 0.075 \\
Sound-noise level (TC4) & $1 / 2$ & $1 / 3$ & 2 & 1 & 0.143 \\
Suitability for disadvantaged people (TC5) & $1 / 3$ & $1 / 6$ & 1 & $1 / 2$ & 1 \\
\hline
\end{tabular}

$\lambda \max =5.0571 \mathrm{CR}=0.0127<0.10$

book a seat next to the opposite sex (see T4). This situation was found to be of third-degree significance among the criteria (weight ranking $\mathrm{T} 2>\mathrm{T} 3>\mathrm{T} 4>\mathrm{T} 1$ ).

The consistency of the personnel behavior sub-criteria matrix is high. It is seen that the behaviors of the service and booking personnel were scored are more weighted (Table 11; weight ranking PB1> PB3> PB4> PB2).

The consistency of the train comfort sub-criteria matrix is quite high (Table 12). It is possible to say that the most important criterion in train comfort is the width of the seating areas (weight ranking TC2> TC1 $>$ TC4> TC3 $=$ TC5). To accurately measure the satisfaction with the seating areas on trains, only economy class users were surveyed, the business-class with a larger and more comfortable seat is not included in the study.

When the AHP results are examined; the criteria with the highest total weight scores, trip frequency (T2), ticket price (F1) and trip times (T3) seem to have more impact on passenger satisfaction (Table 13).

At this stage of the study, according to the variables of gender, age, education, income and trip purposes, the mean scores of the participants regarding HSR satisfaction were analyzed by multiplying the total weights of the criteria (Table A.2-3). When the gender variable is examined (Table A.2), female participants $(\bar{x}=3.2116)$ seem to have a very close satisfaction score with male

Table 13. Results of AHP analysis

\begin{tabular}{lccccccccc}
\hline Main criteria & MW & SCC & SW & TW & Main criteria & MW & SCC & SW & TW \\
\hline Security and risk (S) & 0.089 & S1 & 0.508 & 0.04521 & Trip comfort (T) & 0.452 & T1 & 0.047 & 0.02124 \\
& 0.089 & S2 & 0.160 & 0.01424 & & 0.452 & T2 & 0.510 & 0.23052 \\
& 0.089 & S3 & 0.276 & 0.02456 & & 0.452 & T3 & 0.305 & 0.13786 \\
& 0.089 & S4 & 0.056 & 0.00498 & & 0.452 & T4 & 0.138 & 0.06238 \\
Fare and ticket services (F) & 0.233 & F1 & 0.701 & 0.16333 & Station comfort (SC) & 0.054 & SC1 & 0.096 & 0.00518 \\
& 0.233 & F2 & 0.193 & 0.04497 & & 0.054 & SC2 & 0.251 & 0.01355 \\
& 0.233 & F3 & 0.106 & 0.02470 & & 0.054 & SC3 & 0.653 & 0.03526 \\
Train comfort (TC) & 0.138 & TC1 & 0.221 & 0.03050 & Personnel behavior (PB) & 0.034 & PB1 & 0.467 & 0.01588 \\
& 0.138 & TC2 & 0.486 & 0.06707 & & 0.034 & PB2 & 0.079 & 0.00269 \\
& 0.138 & TC3 & 0.075 & 0.01035 & & 0.034 & PB3 & 0.315 & 0.01071 \\
& 0.138 & TC4 & 0.143 & 0.01973 & & 0.034 & PB4 & 0.139 & 0.00473 \\
& 0.138 & TC5 & 0.075 & 0.01035 & & & &
\end{tabular}

MW: Main criteria weights; SCC: Sub criteria codes; SW: Sub criteria weights; TW: total weights. 
participants $(\bar{x}=3.2016)$, however, it is observed that they differ in trip comfort and security and risk criteria. Female participants were less satisfied with the security measures (S3) taken in the station and its vicinity and theft and harassment measures (S2) inside the train. Male participants, on the other hand, find the trip frequencies (T2) to be insufficient. This result may be associated with the fact that male passengers use trains more frequently (Female passengers use HSR an average of 48 days a year, while male passengers use 67 days).

While examining satisfaction levels by age variable, the data were rearranged according to the 3 -age group. Since the age at first employment is mostly (32.1\%) 25 years in Turkey (TUIK, 2019), the 18-24 age group constitutes the youth group that is considered to be not included in the working life, while the 25-54 age group forms the second group of youth-middle age, and 55 and over group was the third group of early aged-aged group. HSR general satisfaction level decreases with increasing age (Table A.2). Participants aged 55 and over find HSR safer. The same age group scored lower on train comfort (especially to ventilation and heating systems) than other participants (18-24 years $\bar{x}=0.5395 ; 25-54$ years $\bar{x}=0.5373 ; 55$ and over $\bar{x}=0.4961$ ). Another problem for the 55 and over age group is the fact that stations are not suitable for climate conditions (SC3). While the 25-54 age group does not find the trip frequency (T2) sufficient, they are also not satisfied with the sex discrimination in the seats (T4). Compared to other participants, participants in the 18-24 age group stated that accessibility to ticket services are satisfactory. This result may be associated with the new generation's relative ease in use of technology (buying tickets using the website or a smartphone, etc.).

In terms of ease of comparison in the training variable, the classification was done as follows: literate, primary and secondary school graduates in the first group; high school and college graduates in the second group; bachelor and postgraduate graduates in the third group. When general satisfaction scores are examined (Table A.2); it is found that as the education level increases, satisfaction with HSR decreases (elementary and below $\bar{x}=3.4054$; high school and equivalent $\bar{x}=3.2118$; bachelor and above $\bar{x}=3.1092$ ). Similarly, the total satisfaction scores of security and risk, station comfort and trip comfort are inversely proportional to the level of education. Participants with bachelor and higher education find the security measures (S3) in the station and its vicinity insufficient.

When analyzing income data, evaluations were made in three categories: subminimum rate, minimum wage $(1,603$ YTL), and above minimum wage. Total satisfaction scores of fare and ticket services seem to be directly proportional to income, while station comfort total satisfaction scores are inversely proportional to income (Table A.3). It is an expected result that satisfaction with ticket prices (F1) will decrease in the low income group. The conformity of the stations to climatic conditions (SC3) is scored lower by individuals with minimum wage or higher income. In addition, these two income groups have low satisfaction with trip comfort.

HSR travel purposes are divided into seven categories: participation in socio-cultural events, visiting of relatives, friend visits, business and business follow-up, health services, education services, and elderly, patient, child care services. Looking at the overall satisfaction scores, participants traveling with the purpose of visiting friends $(\bar{x}=3.4316)$ and participating in socio-cultural activities $(\bar{x}=3.3728)$ are more satisfied with HSR. Participants traveling for elderly, patient or childcare services have the lowest overall satisfaction score $(\bar{x}=3.0336)$. Trip comfort scores were lower in business and business follow-up purpose trips, while security and risk and train and station comfort scores were lower in the trips for health care purposes, and fare and ticket services total scores were lower in care-purposed trips. Participants who stated that they traveled for access to health services do not find the station platform (SC2), the suitability of the stations for climatic conditions (SC3) and the width of the seats (TC2) inside the train sufficient. Ticket prices (F1) in the trips for education and care services and gender discrimination in seats (T4) in the trips for business and business follow-up and education purposes are other criticized issues.

\section{Limitations of the Study and Future Research}

The most important limitation of the study is the the data set comprising of only HSR passengers between Ankara-Konya route. It was not possible to apply the questionnaires simultaneously on other HSR routes; therefore, it is not possible to generalize the satisfaction level for all HSR services. However, it is thought that the study will contribute to the further studies in terms of determining the method and satisfaction criteria.

The second limitation is the fact that satisfaction with security and risk cannot be measured with the absolute perceptions. Security and risk are related to social memory as well as one's own experiences. As a matter of fact, no accident, terrorist attack or similar incident occurred in TCDD's Ankara-Konya trips until the date of the questionnaire. Due to this social memory, passengers' confidence in HSR is already (in a prejudiced way) high. However, approximately seven months after the questionnaires were conducted (on December 13, 2018), the train on the Ankara-Konya route crashed in Ankara, 9 people died and 47 were injured. Officials explained that the accident was caused by signaling problems, all 
trip services departing from Ankara continued for a long time in a delayed manner. The question of how this fact, which will directly affect the safety and risk satisfaction of the passengers and indirectly the satisfaction of trip comfort, would affect further studies is uncertain. Similar uncertainty is true of satisfaction with the ticket prices, as a matter of fact, as of October 7, 2019, TCDD started to offer ticket prices with a $20 \%$ increase. In this context, comparing the safety level, ticket prices and trip satisfaction measurements within this study in additional studies will be useful for monitoring the changes over time.

\section{Conclusion and Further Discussions}

High speed railways are considered as one of the most important technological developments in passenger transportation today. In recent years, supply and demand for HSR transportation has increased in intercity trips. In this context, this study provides a different approach to the assessment of HSR passenger satisfaction. The study aims to measure satisfaction, thus both main and sub-criteria are weighted using AHP method and then, satisfaction of different socio-demographic passenger groups is measured by considering these weighted scores. Based on the AHP results, the trip comfort and train comfort criteria had high, while fare and ticket services and security and risk criteria had medium, and station comfort and personnel behavior criteria had lower weighted scores. In this regard, the results reveal that trip and train comfort is important factors for increasing HSR passenger satisfaction and this result was found to be similar to the studies of Chin et al. (2019), de Oña et al.(2018), Harvey et al. (2014). While security and risk affects the satisfaction at medium level (Aydin et al., 2015; Nandan, 2010; Harvey et al., 2014; Nathanail, 2008; Vanniarajan \& Stephen, 2008), the least impact is related to the personnel behavior. However, it is possible to claim that the low effect of personnel behavior on satisfaction is contradictory with some studies in the literature (Agarwal, 2008; Alpu, 2015; Chin et al., 2019; Ghosh \& Ojha, 2017; Zhen et al., 2018).

According to AHP results, among the 6 main criteria, the sub criteria of ticket prices, the conformity of stations to the climate conditions, trip frequency, security measures for emergencies and disasters, width of seats, behavior of service personnel are the sub-criteria with the highest score (see Table 13, sub criteria weights). When it is evaluated with the main criterion weights, on the other hand, it is found that the frequency of voyages, ticket prices and trip times sub-criteria have more impact on satisfaction. In the context of these criteria (in total scores), young passengers (18-24 years old) with primary and lower education traveling for the purpose of visiting relatives and friends seem to be more satisfied with HSR, while as the level of education, income and age increase, it is seen that expectations from HSR increase,and satisfaction decreases.

Hence, to increase passenger satisfaction by providing a higher quality HSR service in the future, TCDD needs to analyze the different socio-demographic variables well and develop new strategies for some groups. For example, satisfaction with ticket prices, which is an important criterion, is very low for the low income group. After TCDD raises the ticket prices, the gap between the train and bus ticket prices has closed. Passengers prefer HSR because they save their time, however, if, in the future, the new price raises would carry the fares over the bus ticket prices, this may cause low-income passengers to prefer the bus. This could negatively affect the HSR operations in the long-term.

In addition to pricing policies, age is a significant factor in passenger satisfaction. For instance, since the group of 55 and over age group are more affected from heat and cold, those in this group state that the stations are not suitable for climatic conditions. Similarly, these people scored the ventilation and heating systems in the train with lower scores. Another problem stated by this age group is the inability to access booking services as easily as young people since they are not able to use technology like them. In this context, TCDD should review HSR services with an age-sensitive approach and take different measures (increasing the closed areas at the stations, controlling the carrier air conditioners, preparation of brochures describing online ticket purchase, etc.).

Another significant result of the study is that, female and highly-educated passengers think that safety measures before and during the trip are not sufficient. This result may be associated with the fact that Turkey is a country with high risk of disaster and terrorism and defects in the protective legal system. For this reason, firstly, enforcements and inspections regarding security breach should be increased. Individuals traveling for the purpose of care services or health services such as elderly, sick, children have lower HSR satisfaction than other passengers. The station platform, the conformity of the stations for the climatic conditions and the width of the seats in the train are not deemed to be sufficient by these people. The design of the stations and platforms should be revised for these vulnerable groups. However, increasing the areas reserved for disabled people in the train and allocation of larger and more comfortable seats for passengers who are sick or accompany any person in need of care would have a positive impact on HSR satisfaction.

All in all, as being the most efficient and highly preferred public transport mode in terms of intercity transportation HSR promises a lot for the future. On the other hand, HSR operators need to pay attention to user satisfaction in order to both provide better services and increase their 
monetary gains. In this context, this study provides an overview for the case of user satisfaction by focusing on the Ankara-Konya route while similar studies should be conducted at other locations to derive more general results and enhance passenger satisfaction during HSR trips.

\section{References}

Agarwal, R. (2008). Public transportation and customer satisfaction: the case of Indian railways. Global Business Review, $9(2), 257-272$.

Allen, W. G., DiCesare, F. (1976). Transit service evaluation: preliminary identification of variables characterizing level of service. Transportation Research Record, 606, 41-47.

Alpu, O. (2015). A methodology for evaluating satisfaction with high-speed train services: a case study in Turkey. Transport Policy, 44, 151-157.

Anderson, E. W., Sullivan, M. W. (1993). The antecedents and consequences of customer satisfaction for firms. Marketing Science, 12(2), 125-143.

Aydin, N., Celik, E., Gumus, A. T. (2015). A hierarchical customer satisfaction framework for evaluating rail transit systems of Istanbul. Transportation Research Part A: Policy and Practice, 77, 61-81.

Cao, C., Chen, J. (2011). An empirical analysis of the relationship among the service quality, customer satisfaction and loyalty of high speed railway based on structural equation model. Canadian Social Science, 7(4), 67-73.

Chen, C. F. (2008). Investigating structural relationships between service quality, perceived value, satisfaction, and behavioral intentions for air passengers: evidence from Taiwan. Transportation Research Part A: Policy and Practice, 42(4), 709717.

Cheng, Y. H. (2011). Evaluating web site service quality in public transport: evidence from Taiwan high speed rail. Transportation Research Part C: Emerging Technologies, 19(6), 957-974.

Cheng, Y. H., Huang, T. Y. (2014). High speed rail passenger segmentation and ticketing channel preference. Transportation Research Part A: Policy and Practice, 66(1), 127-143.

Chin, K. S., Yang, Q., Chan, C. Y. P., Tsui, K. L., Li, Y. L. (2019). Identifying passengers' needs in cabin interiors of high-speed rails in china using quality function deployment for improving passenger satisfaction. Transportation Research Part A: Policy and Practice, 119(June 2018), 326-342.

Chou, J. S., Kim, C. (2009). A structural equation analysis of the QSL relationship with passenger riding experience on high speed rail: an empirical study of Taiwan and Korea. Expert Systems with Applications, 36(3 Part 2), 6945-6955.

Chou, J. S., Kim, C., Kuo, Y. C., Ou, N. C. (2011). Deploying effective service strategy in the operations stage of high-speed rail. Transportation Research Part E: Logistics and Transportation Review, 47(4), 507-519.

De Oña, J., De Oña, R., Eboli, L., Forciniti, C., Mazzulla, G. (2018). an ordered regression model to predict transit passengers' behavioural intentions. Case Studies on Transport Policy, 6(4), 449-455.

Dell'Olio, L., Ibeas, A., Cecin, P. (2011). The quality of service desired by public transport users. Transport Policy, 18(1), 217227.
Drea, J. T., Hanna, J. B. (2000). Niche marketing in intrastate passenger rail transportation. Transportation Journal, 39(3), 3343.

Eroğlu, E. (2005). Müşteri memnunīyeti ölçüm modelï. i.ü. İşletme Fakültesi İşletme Dergisi, 34(1), 7-25.

Ghosh, P., Ojha, M. K., (2017). Determining passenger satisfaction out of platform-based amenities: a study of Kanpur central railway station. Transport Policy, 60(June), 108-118.

Hanna, J. B., Drea, J. T. (1998). Understanding and predicting passenger rail travel: an empirical study. Transportation Journal, 38(1), 38-46.

Harvey, J., Thorpe, N., Caygill, M., Namdeo, A. (2014). Public attitudes to and perceptions of high speed rail in the UK. Transport Policy, 36, 70-78.

Hu, H. H., Kandampully, J., Juwaheer, D. D. (2009). Relationships and impacts of service quality, perceived value, customer satisfaction, and image: an empirical study. Service Industries Journal, 29(2), 111-125.

Jen, W., Hu, K. C. (2003). Application of perceived value model to identify factors affecting passengers' repurchase intentions on city bus: a case of the Taipei metropolitan area. Transportation, 30(3), 307-327.

Joewono, T. B., Kubota, H. (2007). User satisfaction with paratransit in competition with motorization in Indonesia: anticipation of future implications. Transportation, 34(3), 337-354.

Kilibarda, M., Nikolicic, S., Andrejic, M. (2016). Measurement of logistics service quality in freight forwarding companies: a case study of the Serbian market. The International Journal of Logistics Management, 27(3), 770-794.

Kotler, P. (1997). Marketing management-analysis, planning, implementation and control. Prentice Hall.

Kuo, C.-W., Tang, M.-L. (2011). Survey and empirical evaluation of nonhomogeneous arrival process models with taxi data. Journal of Advanced Transportation, 47(June 2010), 512-525.

Lai, W. T., Chen, C. F. (2011). Behavioral intentions of public transit passengers-the roles of service quality, perceived value, satisfaction and involvement. Transport Policy, 18(2), 318-325.

Lao, Y., Liu, L. (2009). Performance evaluation of bus lines with data envelopment analysis and geographic information systems. Computers, Environment and Urban Systems, 33(4), 247-255.

Lee, A. H. I., Chen, H. H., Kang, H. Y. (2009). Multi-criteria decision making on strategic selection of wind farms. Renewable Energy, 34(1), 120-126.

Liu, Jia, Zhao, P. (2005). Constructing quality-satisfaction-loyalty chain system: an empirical study of insurance industry in China. International Conference on Services Systems and Services Management, Proceedings of ICSSSM'05, 2, 1237-1241.

Liu, Jian, Zhang, N. (2012). Empirical research of intercity highspeed rail passengers' travel behavior based on fuzzy clustering model. Journal of Transportation Systems Engineering and Information Technology, 12(6), 100-105.

Liu, Y., Yang, M. (2018). Analysis of passenger satisfaction for bus line based on analytic hierarchy process. DEStech Transactions on Social Science, Education and Human Science, 140144.

Miller, M. (1995). Improving Customer service and satisfaction at London underground. Managing Service Quality: An International Journal, 5(1), 26-29. 
Mouwen, A., Rietveld, P. (2013). Does competitive tendering improve customer satisfaction with public transport? A case study for the Netherlands. Transportation Research Part A: Policy and Practice, 51, 29-45.

Nandan, S. (2010). determinants of customer satisfaction on service quality: a study of railway platforms in India. Journal of Public Transportation, 13(1), 97-113.

Nathanail, E. (2008). Measuring the quality of service for passengers on the Hellenic railways. Transportation Research Part A: Policy and Practice, 42(1), 48-66.

Olsen, S. O. (2002) Comparative Evaluation and the Relationship Between Quality, Satisfaction, and Repurchase Loyalty, Journal of the Academy of Marketing Science, 30(3), 240-249.

Parasuraman, A., Zeithaml, V. A., Berry, L. L. (1988). A multiple item scale for measuring consumer perceptions of service quality. Journal of Retailing, 64(1), 12-14.

Pollitt, M. G., Smith, A. S. J. (2002). The restructuring and privatisation bad? Fiscal Studies, 23(4), 463-502.

Pullen, W. T. (1993). Definition and measurement of quality of service for local public transport management: foreign summaries. Transport Reviews, 13(3), 247-264.

Redman, L., Friman, M., Gärling, T., Hartig, T. (2013). Quality attributes of public transport that attract car users: a research review. Transport Policy, 25, 119-127.

Rothbauer, J., Sieg, G. (2011). Quality standards for passenger trains: political majorities and environmental costs. Transportation Research Part D: Transport and Environment, 16(2), 178-182.

Saaty, T. L. (1980). The analytic hierarchy process, Mc Graw-Hill.

Saaty, T. L. (1990). How to make a decision: the analytic hierarchy process. European Journal of Operational Research, 48(1), 9-26.

Saaty, T. L. (2008). Decision making with the analytic hierarchy process. International Journal of Services Sciences, 1(1), 8398.

Silcock, D. T. (1981). Measures of operational performance for urban bus services. Traffic Engineering Control, 22(12), 645648.

Tang, J., Zhen, F., Cao, J., Mokhtarian, P. L. (2018). How do passengers use travel time? a case study of Shanghai-Nanjing high speed rail. Transportation, 45(2), 451-477.
Uludağ, A. S., Doğan, H. (2016). Çok kriterli karar verme yöntemlerinin karşılaştırılmasına odaklı bir hizmet kalitesi uygulaması. Çankırı Karatekin Üniversitesi İktisadi ve İdari Bilimler Fakültesi Dergisi, 6(2), 17-48.

Vanniarajan, T., Stephen, A. (2008). Railqual and passengers satisfaction: an empirical study in southern railways. Asia Pacific Business Review, 4(1), 64-75.

Wang, Y., Chen, R., Zhao, P. (2007). The determinants of customer satisfaction after service failure and recovery. ICSSSM'07: 2007 International Conference on Service Systems and Service Management, 1-5.

Wu, J. H. C., Lin, Y. C., Hsu, F. S. (2011). An empirical analysis of synthesizing the effects of service quality, perceived value, corporate image and customer satisfaction on behavioral intentions in the transport industry: a case of Taiwan highspeed rail. Innovative Marketing, 7(3), 83-100.

Xiaoqiang, Z., Lang, M., Jin, Z. (2017). Dynamic pricing for passenger groups of high-speed rail transportation. Journal of Rail Transport Planning and Management, 6(4), 346-356.

Zeybek, H. (2018). Customer segmentation strategy for rail freight market: the case of Turkish state railways. Research in Transportation Business and Management, 28(June), 45-53.

Zhao, W., Xu, L., Dong, Z. S., Qi, B., Qin, L. (2018). Improving transfer feasibility for older travelers inside high-speed train station. Transportation Research Part A: Policy and Practice,113(July 2016), 302-317.

Zhen, F., Cao, J., Tang, J. (2018). Exploring correlates of passenger satisfaction and service improvement priorities of the Shanghai-Nanjing high speed rail. Journal of Transport and Land Use, 11(1), 559-573.

Ray Haber (November 15, 2020) https://rayhaber.com/2019/08/ tcdd-demiryolu-guzergahlari-ve-yht-hatlari-haritasi-2019-guncel/

TCDD. (May 15, 2018). Activity Report. http://www.tcddtasimacilik.gov.tr/uploads/images/3/Strateji/Faaliyet_Raporlari/ faaliyet_raporu_2018.pdf

TUIK. (December 10, 2019). Household Statistics. http://www. tuik.gov.tr/PreHaberBultenleri.do?id=8507 tb_id=6

UIC. (July 11, 2019). High-Speed Rail History. https://uic.org/ passenger/highspeed/High-Speed-History\#t19th-20th-CENTURY-From-birth-of-railways-to-HSR6 
Table A.1. Some customer satisfaction criteria using in the literature

\begin{tabular}{|c|c|c|}
\hline & Criteria & Researchers \\
\hline \multirow[t]{10}{*}{ Public transport } & Website service quality & Cheng (2011) \\
\hline & $\begin{array}{l}\text { Customer service, tangible service equipment, availability of the service, individual } \\
\text { space, accessibility, information, security, environmental pollution (noise, vibration) }\end{array}$ & de Oña et al., (2018) \\
\hline & Cleanliness, comfort, time of waiting & Dell'Olio et al., (2011) \\
\hline & $\begin{array}{l}\text { Availability, accessibility, reliability, information, customer service, comfort, safety, } \\
\text { price and environmental impact }\end{array}$ & Joewono \& Kubota (2007) \\
\hline & $\begin{array}{l}\text { Reliability, comfort, security, information, personnel behavior, cleanliness, } \\
\text { ticketing and price }\end{array}$ & Lao \& Liu (2009) \\
\hline & Service frequency, trip speed, precision & Mouwen \& Rietveld (2013) \\
\hline & Reliability, responsiveness, tangibility, assurance, empathic & Parasuraman et al., (1988) \\
\hline & Accessibility, reliability, comfort, convenience and safety & Pullen (1993) \\
\hline & Service security, frequency & Redman et al., (2013) \\
\hline & Accessibility, reliability, comfort, convenience and security & Silcock (1981) \\
\hline \multirow[t]{17}{*}{ Railway } & Service quality, fare & Allen \& DiCesare (1976) \\
\hline & Physical conditions, food services, information ve personnel behavior & Alpu (2015) \\
\hline & $\begin{array}{l}\text { Train comfort, ticketing, information systems, safety, accessibility, station comfort, } \\
\text { welcoming, fare, time }\end{array}$ & Aydin et al., (2015) \\
\hline & $\begin{array}{l}\text { Well-transmitted information, proper luggage storage, sensory comfort, civilized } \\
\text { riding environment, well-prepared facilities }\end{array}$ & Chin et al., (2019) \\
\hline & $\begin{array}{l}\text { Security, station, shuttle service, information and communication technologies, } \\
\text { information availability, attitude of the official, cleanliness, personal space in } \\
\text { the train, air-condition, comfort, the design of the waiting area, route, frequency, } \\
\text { arrival times, ticket service system, frequency of complaints, price tolerance }\end{array}$ & Chou et al., (2011) \\
\hline & Comfortable seat, cleanliness of sitting area & Drea \& Hanna (2000) \\
\hline & $\begin{array}{l}\text { Safety and security, basic facilities, information system, behavioral factors ve } \\
\text { refreshments }\end{array}$ & Nandan (2010) \\
\hline & Reliability, safety, convenience, comfort, flexibility, cost, travel time, amenities & Harvey et al., (2014) \\
\hline & Reliability, safety and security, convenience, comfort & Miller (1995) \\
\hline & $\begin{array}{l}\text { Cleanliness, itinerary accuracy, system safety, passenger comfort, servicing, and } \\
\text { passenger information }\end{array}$ & Nathanail (2008) \\
\hline & Train performance, overcrowding, safety or accident risk & Pollitt \& Smith (2002) \\
\hline & Passengers' waiting time, lost mileage, characteristics of each travel mode & Pullen (1993) \\
\hline & Safety, cleanliness, passenger comfort, service frequency, speed & Rothbauer \& Sieg (2011) \\
\hline & Stable internet connections, sufficient sockets and noiseless trip environment & Tang et al., (2018) \\
\hline & Reliability, assurance, empathy for passengers & Vanniarajan \& Stephen (2008) \\
\hline & $\begin{array}{l}\text { Transit time, availability of wagons, accessibility, loss and damage, secure } \\
\text { transport, reliability, flexibility, distance, technical equipment, price-quality ratio }\end{array}$ & Zeybek (2018) \\
\hline & Staff attitude, ease of booking, accessibility & Zhen et al., (2018) \\
\hline
\end{tabular}


Table A.2. Satisfaction score averages by variables of gender, age and educational background

\begin{tabular}{|c|c|c|c|c|c|c|c|c|c|c|}
\hline \multirow[b]{2}{*}{ Main Criteria } & \multirow[b]{2}{*}{ Code } & \multirow[b]{2}{*}{ Weight } & \multicolumn{2}{|c|}{ Gender } & \multicolumn{3}{|c|}{ Age } & \multicolumn{3}{|c|}{ Education } \\
\hline & & & Female & Male & $18-24$ age & $25-54$ age & 55 and over & $\begin{array}{c}\text { Primary \& } \\
\text { below }\end{array}$ & $\begin{array}{l}\text { High s. \& } \\
\text { equivalent }\end{array}$ & $\begin{array}{l}\text { Bachelor } \\
\text { and over }\end{array}$ \\
\hline \multirow{5}{*}{$\begin{array}{l}\text { Security and } \\
\text { risk (S) }\end{array}$} & S1 & 0.04521 & 0.1537 & 0.1533 & 0.1542 & 0.1505 & 0.1619 & 0.1727 & 0.1524 & 0.1474 \\
\hline & S2 & 0.01424 & 0.0386 & 0.0488 & 0.0440 & 0.0443 & 0.0477 & 0.0493 & 0.0441 & 0.0434 \\
\hline & S3 & 0.02456 & 0.0567 & 0.0813 & 0.0651 & 0.0717 & 0.0793 & 0.0725 & 0.0742 & 0.0690 \\
\hline & S4 & 0.00498 & 0.0179 & 0.0200 & 0.0184 & 0.0196 & 0.0181 & 0.0190 & 0.0192 & 0.0192 \\
\hline & & Total & 0.2669 & 0.3034 & 0.2817 & 0.2862 & 0.3070 & 0.3134 & 0.2899 & 0.2791 \\
\hline \multirow{4}{*}{$\begin{array}{l}\text { Fare and ticket } \\
\text { services (F) }\end{array}$} & F1 & 0.16333 & 0.4606 & 0.4639 & 0.4410 & 0.4786 & 0.4328 & 0.4688 & 0.4590 & 0.4704 \\
\hline & F2 & 0.04497 & 0.1664 & 0.1664 & 0.1713 & 0.1623 & 0.1745 & 0.1704 & 0.1664 & 0.1628 \\
\hline & F3 & 0.02470 & 0.0882 & 0.0892 & 0.0931 & 0.0860 & 0.0855 & 0.0879 & 0.0897 & 0.0860 \\
\hline & & Total & 0.7152 & 0.7194 & 0.7054 & 0.7269 & 0.6928 & 0.7271 & 0.7150 & 0.7191 \\
\hline \multirow{4}{*}{$\begin{array}{l}\text { Station comfort } \\
\text { (SC) }\end{array}$} & $\mathrm{SC} 1$ & 0.00518 & 0.0152 & 0.0135 & 0.0149 & 0.0137 & 0.0146 & 0.0157 & 0.0141 & 0.0133 \\
\hline & SC2 & 0.01355 & 0.0416 & 0.0371 & 0.0398 & 0.0385 & 0.0386 & 0.0432 & 0.0385 & 0.0355 \\
\hline & $\mathrm{SC} 3$ & 0.03526 & 0.0927 & 0.0987 & 0.1005 & 0.0973 & 0.0931 & 0.1097 & 0.0948 & 0.0903 \\
\hline & & Total & 0.1496 & 0.1494 & 0.1552 & 0.1495 & 0.1463 & 0.1686 & 0.1474 & 0.1391 \\
\hline \multirow[t]{5}{*}{ Trip comfort (T) } & $\mathrm{T} 1$ & 0.02124 & 0.0797 & 0.0794 & 0.0767 & 0.0811 & 0.0816 & 0.0837 & 0.0777 & 0.0850 \\
\hline & $\mathrm{T} 2$ & 0.23052 & 0.7192 & 0.6916 & 0.7423 & 0.6731 & 0.7284 & 0.7999 & 0.7031 & 0.6501 \\
\hline & T3 & 0.13786 & 0.4425 & 0.4191 & 0.4384 & 0.4232 & 0.4301 & 0.4715 & 0.4274 & 0.4108 \\
\hline & T4 & 0.06238 & 0.1797 & 0.1772 & 0.1940 & 0.1753 & 0.2021 & 0.1597 & 0.1903 & 0.1709 \\
\hline & & Total & 1.4211 & 1.3673 & 1.4513 & 1.3528 & 1.4422 & 1.5148 & 1.3984 & 1.3168 \\
\hline Personnel & PB1 & 0.01588 & 0.0624 & 0.0594 & 0.0594 & 0.0615 & 0.0602 & 0.0626 & 0.0603 & 0.0616 \\
\hline \multirow[t]{4}{*}{ behavior (PB) } & PB2 & 0.00269 & 0.0105 & 0.0098 & 0.0099 & 0.0102 & 0.0105 & 0.0105 & 0.0101 & 0.0102 \\
\hline & PB3 & 0.01071 & 0.0412 & 0.0391 & 0.0394 & 0.0402 & 0.0401 & 0.0406 & 0.0399 & 0.0403 \\
\hline & PB4 & 0.00473 & 0.0144 & 0.0144 & 0.0146 & 0.0140 & 0.0162 & 0.0156 & 0.0143 & 0.0142 \\
\hline & & Total & 0.1286 & 0.1227 & 0.1233 & 0.1258 & 0.1269 & 0.1293 & 0.1246 & 0.1262 \\
\hline Train comfort & $\mathrm{TC} 1$ & 0.0305 & 0.1171 & 0.1229 & 0.1226 & 0.1199 & 0.1125 & 0.1202 & 0.1226 & 0.1193 \\
\hline \multirow[t]{5}{*}{ (TC) } & TC2 & 0.06707 & 0.2723 & 0.2703 & 0.2743 & 0.2703 & 0.2602 & 0.2763 & 0.2696 & 0.2703 \\
\hline & TC3 & 0.01035 & 0.0377 & 0.0387 & 0.0397 & 0.0393 & 0.0203 & 0.0392 & 0.0384 & 0.0369 \\
\hline & TC4 & 0.01973 & 0.0649 & 0.0681 & 0.0637 & 0.0689 & 0.0653 & 0.0742 & 0.0673 & 0.0649 \\
\hline & TC5 & 0.01035 & 0.0383 & 0.0394 & 0.0391 & 0.0389 & 0.0378 & 0.0423 & 0.0385 & 0.0375 \\
\hline & & Total & 0.5303 & 0.5394 & 0.5395 & 0.5373 & 0.4961 & 0.5522 & 0.5364 & 0.5289 \\
\hline \multicolumn{3}{|c|}{ Overall satisfaction score * ortalama } & 3.2116 & 3.2016 & 3.3943 & 3.3726 & 3.3383 & 3.4054 & 3.2118 & 3.1092 \\
\hline
\end{tabular}

*The overall satisfaction score was evaluated over 5 points. 
Table A.3. Satisfaction score averages according to income and travel purpose variables

\begin{tabular}{|c|c|c|c|c|c|c|c|c|c|c|c|c|}
\hline \multirow[b]{2}{*}{ Main Criteria } & \multirow[b]{2}{*}{ Code } & \multirow[b]{2}{*}{ Weight } & \multicolumn{3}{|c|}{ Income } & \multicolumn{7}{|c|}{ Trip purpose } \\
\hline & & & $\begin{array}{l}\text { Sub- } \\
\text { minimum } \\
\text { rate }\end{array}$ & $\begin{array}{l}\text { Minimium } \\
\text { wage }\end{array}$ & $\begin{array}{c}\text { Over } \\
\text { minimum } \\
\text { wage }\end{array}$ & $\begin{array}{c}\text { Visiting } \\
\text { of } \\
\text { relative }\end{array}$ & $\begin{array}{l}\text { Business } \\
\text { and } \\
\text { follow-up }\end{array}$ & $\begin{array}{c}\text { Health } \\
\text { services }\end{array}$ & $\begin{array}{c}\text { Friend } \\
\text { visit }\end{array}$ & $\begin{array}{l}\text { Participation } \\
\text { in social and } \\
\text { cultural events }\end{array}$ & Education & $\begin{array}{c}\text { Care } \\
\text { services }\end{array}$ \\
\hline \multicolumn{13}{|c|}{ Security and risk } \\
\hline \multirow[t]{5}{*}{ (S) } & S1 & 0.0452 & 0.1542 & 0.1569 & 0.1501 & 0.1542 & 0.1564 & 0.1388 & 0.1524 & 0.1442 & 0.1496 & 0.1695 \\
\hline & $\mathrm{S} 2$ & 0.0142 & 0.0436 & 0.0457 & 0.0451 & 0.0453 & 0.0466 & 0.0409 & 0.0440 & 0.0443 & 0.0417 & 0.0392 \\
\hline & S3 & 0.0246 & 0.0648 & 0.0732 & 0.0734 & 0.0928 & 0.0756 & 0.0656 & 0.0771 & 0.0673 & 0.0661 & 0.0553 \\
\hline & S4 & 0.0050 & 0.0191 & 0.0199 & 0.0192 & 0.0192 & 0.0203 & 0.0173 & 0.0204 & 0.0194 & 0.0181 & 0.0174 \\
\hline & & Total & 0.2817 & 0.2956 & 0.2879 & 0.3115 & 0.2989 & 0.2625 & 0.2938 & 0.2752 & 0.2755 & 0.2814 \\
\hline \multicolumn{13}{|c|}{ Fare and ticket services } \\
\hline \multirow[t]{4}{*}{ (F) } & $\mathrm{F} 1$ & 0.1633 & 0.3724 & 0.4508 & 0.5063 & 0.4639 & 0.4606 & 0.5227 & 0.4949 & 0.4900 & 0.4198 & 0.3267 \\
\hline & $\mathrm{F} 2$ & 0.0450 & 0.1704 & 0.1614 & 0.1646 & 0.1641 & 0.1614 & 0.1619 & 0.1749 & 0.1601 & 0.1632 & 0.1574 \\
\hline & F3 & 0.0247 & 0.0936 & 0.0897 & 0.0840 & 0.0931 & 0.0845 & 0.0823 & 0.0973 & 0.0897 & 0.0921 & 0.0926 \\
\hline & & Total & 0.6364 & 0.7019 & 0.7549 & 0.7211 & 0.7065 & 0.7668 & 0.7671 & 0.7397 & 0.6751 & 0.5767 \\
\hline \multicolumn{13}{|l|}{ Station comfort } \\
\hline \multirow[t]{4}{*}{ (SC) } & SC1 & 0.0052 & 0.0147 & 0.0140 & 0.0135 & 0.0145 & 0.0130 & 0.0114 & 0.0154 & 0.0133 & 0.0150 & 0.0142 \\
\hline & $\mathrm{SC} 2$ & 0.0136 & 0.0390 & 0.0398 & 0.0371 & 0.0400 & 0.0352 & 0.0316 & 0.0419 & 0.0377 & 0.0394 & 0.0305 \\
\hline & $\mathrm{SC} 3$ & 0.0353 & 0.1312 & 0.0991 & 0.0910 & 0.0959 & 0.0980 & 0.0776 & 0.1008 & 0.0927 & 0.0903 & 0.1058 \\
\hline & & Total & 0.1849 & 0.1529 & 0.1416 & 0.1504 & 0.1462 & 0.1205 & 0.1581 & 0.1437 & 0.1447 & 0.1505 \\
\hline \multicolumn{13}{|l|}{ Trip comfort } \\
\hline \multirow[t]{5}{*}{$(\mathrm{T})$} & $\mathrm{T} 1$ & 0.0212 & 0.0784 & 0.0777 & 0.0811 & 0.0803 & 0.0807 & 0.0822 & 0.0741 & 0.0780 & 0.0756 & 0.0743 \\
\hline & $\mathrm{T} 2$ & 0.2305 & 0.7123 & 0.6708 & 0.6962 & 0.7584 & 0.6593 & 0.7377 & 0.7838 & 0.7861 & 0.6708 & 0.7492 \\
\hline & T3 & 0.1379 & 0.4439 & 0.4260 & 0.4177 & 0.4549 & 0.3984 & 0.4687 & 0.4880 & 0.4701 & 0.4219 & 0.3447 \\
\hline & $\mathrm{T} 4$ & 0.0624 & 0.1990 & 0.1722 & 0.1815 & 0.1934 & 0.1753 & 0.1871 & 0.2177 & 0.2077 & 0.1753 & 0.2339 \\
\hline & & Total & 1.4336 & 1.3467 & 1.3765 & 1.4870 & 1.3137 & 1.4757 & 1.5636 & 1.5419 & 1.3436 & 1.4021 \\
\hline \multicolumn{13}{|c|}{ Personnel behavior } \\
\hline \multirow[t]{5}{*}{ (PB) } & PB1 & 0.0159 & 0.0607 & 0.0603 & 0.0611 & 0.0627 & 0.0611 & 0.0592 & 0.0594 & 0.0586 & 0.0597 & 0.0516 \\
\hline & PB2 & 0.0027 & 0.0102 & 0.0100 & 0.0101 & 0.0106 & 0.0104 & 0.0104 & 0.0099 & 0.0100 & 0.0096 & 0.0108 \\
\hline & PB3 & 0.0107 & 0.0399 & 0.0401 & 0.0395 & 0.0403 & 0.0399 & 0.0407 & 0.0395 & 0.0405 & 0.0395 & 0.0423 \\
\hline & PB4 & 0.0047 & 0.0146 & 0.0154 & 0.0139 & 0.0150 & 0.0149 & 0.0136 & 0.0139 & 0.0147 & 0.0139 & 0.0177 \\
\hline & & Total & 0.1253 & 0.1258 & 0.1246 & 0.1286 & 0.1263 & 0.1239 & 0.1227 & 0.1237 & 0.1227 & 0.1224 \\
\hline \multicolumn{13}{|l|}{ Train comfort } \\
\hline \multirow[t]{6}{*}{ (TC) } & TC1 & 0.0305 & 0.1205 & 0.1193 & 0.1232 & 0.1238 & 0.1205 & 0.1159 & 0.1211 & 0.1232 & 0.1171 & 0.1220 \\
\hline & TC2 & 0.0671 & 0.2757 & 0.2656 & 0.2643 & 0.2790 & 0.2602 & 0.2461 & 0.2622 & 0.2757 & 0.2777 & 0.2649 \\
\hline & TC3 & 0.0104 & 0.0395 & 0.0368 & 0.0379 & 0.0384 & 0.0377 & 0.0359 & 0.0393 & 0.0391 & 0.0389 & 0.0259 \\
\hline & $\mathrm{TC} 4$ & 0.0197 & 0.0639 & 0.0657 & 0.0683 & 0.0651 & 0.0691 & 0.0631 & 0.0677 & 0.0738 & 0.0623 & 0.0592 \\
\hline & TC5 & 0.0104 & 0.0386 & 0.0369 & 0.0392 & 0.0395 & 0.0377 & 0.0373 & 0.0358 & 0.0368 & 0.0369 & 0.0285 \\
\hline & & Total & 0.5382 & 0.5243 & 0.5328 & 0.5459 & 0.5251 & 0.4984 & 0.5261 & 0.5486 & 0.5330 & 0.5005 \\
\hline \multicolumn{3}{|c|}{ Overall satisfaction score * } & 3.2001 & 3.1473 & 3.2184 & 3.3445 & 3.1168 & 3.2479 & 3.4316 & 3.3728 & 3.0946 & 3.0336 \\
\hline
\end{tabular}

*The overall satisfaction score was evaluated over 5 points. 